TITLE:

\title{
Marine Tubificidae (Oligochaeta, Annelida) from Shirahama, Western Japan, With a Description of a New Species
}

\section{$\operatorname{AUTHOR(S):~}$}

Takashima, Yoshikazu; Mawatari, Shunsuke F.

\section{CITATION:}

Takashima, Yoshikazu ...[et al]. Marine Tubificidae (Oligochaeta, Annelida) from

Shirahama, Western Japan, With a Description of a New Species. PUBLICATIONS OF THE SETO MARINE BIOLOGICAL LABORATORY 1997, 38(1-2): 29-36

ISSUE DATE:

1997-12-25

URL:

http://hdl.handle.net/2433/176274

RIGHT: 


\title{
Marine Tubificidae (Oligochaeta, Annelida) from Shirahama, Western Japan, with a Description of a New Species
}

\author{
Yoshikazu Takashima and Shunsuke F. Mawatari \\ Division of Biological Sciences, Graduate School of Science, \\ Hokkaido University, Sapporo 060-0810, Japan
}

\begin{abstract}
Three species of marine Tubificidae, including one new to science are described from Shirahama, Wakayama Prefecture, western Japan. Heterodrilus mediopapillosus sp. $\mathrm{n}$. is characterized by having median papilla in ventral of $\mathrm{X}$, pear-shaped pseudopenes, long penial setae, and presence of spermathecae. Aktedrilus locyi and Limnodriloides tenuiductus are reported from Japan for the first time.
\end{abstract}

Key words: marine Tubificidae, taxonomy, western Japan

\section{Introduction}

Following several studies of marine tubificids from Japan (Baker and Brinkhurst, 1981; Brinkhurst, 1985; Ohtaka, 1987), we recently described eight species from Hokkaido, northern Japan (Takashima and Mawatari, 1996). In these studies a total of nine species belonging to five genera have been reported, but none have been described from the western part of Japan. We therefore expanded the area of our tubificid survey to western Japan. As a result, this second report of our research on Japanese tubificids deals with the species collected from Shirahama, Wakayama Prefecture, western Japan. Among the three species collected, Heterodrilus mediopapillosus sp. n. is described, and the two new records from Japan, Aktedrilus locyi Erséus, 1980 and Limnodriloides tenuiductus Erséus, 1982, are redescribed based on the Japanese material.

\section{Materials and Methods}

All the material was collected by the first author during his short stay at the Seto Marine Biological Laboratory, Kyoto University, Shirahama, Wakayama Prefecture. Specimens of Heterodrilus mediopapillosus sp. $\mathrm{n}$. were obtained from subtidal sediments using a Smith-McIntyre grab. Samples of Aktedrilus locyi and Limnodriloides tenuiductus were collected from intertidal sediments.

Tubificids, extracted from the sediments by decanting and sieving, were sorted under a dissection microscope. Sorted worms were anaesthetized and fixed in $70 \%$ ethanol (Takashima and Mawatari, 1996). Fixed specimens were dehydrated through ethanol series, cleared in xylene, and mounted whole in Canada balsam. Observations were made with Nomarskii differential interference contrast microscopy, and figures were drawn with the aid of a drawing apparatus.

All the material including the type series of Heterodrilus mediopapillosus sp. n. are deposited in the Zoological Institute, Division of Biological Sciences, Graduate School of Science, Hokkaido University (ZIHU), Sapporo, Japan.

Abbreviations of the figures

aa, atrial ampulla; ad, atrial duct; apr, anterior prostate gland; at, atrium; cl, clitellum; cs, copulatory sac; ep, epidermal papilla; mp, male pore; $p$, penis; pa, pseudopenial papilla; pp, pseudopenis; ppr, posterior prostate gland; pr, prostate gland; prp, prostatic pad; ps, penial setac; sf, sperm funnel; sp, spermatheca; spa, spermathecal ampulla; spd, spermathecal duct; spp, spermathecal pore; vd, vas deferens. 


\section{Taxonomy \\ Genus Heterodrilus Pierantoni, 1902 \\ Heterodrilus mediopapillosus sp. $\mathbf{n}$.}

(Fig. 1)

Material examined

Holotype. ZIHU 1042, a whole-mounted specimen. Type locality. Shiso-jima, Shirahama-cho, Wakayama Prefecture, Japan; subtidal $(8.8 \mathrm{~m})$, gravel with shell debris (2 December 1993). Paratypes. ZIHU 1043-1048, 6 whole-mounted specimens; data as for holotype.

Description

External features. Length $12.2-16.5 \mathrm{~mm}$ (large species in the genus); number of segments $53-72$. Width $0.28-0.40 \mathrm{~mm}$ at XI. Prostomium blunt conical, about as long as wide. Clitellum extending over 1/4X-XII. Male and spermathecal pores paired in line with ventral setae, in anterior-most part of $\mathrm{X}$ and posteriorly in XI, respectively. Unpaired epidermal papilla (Fig. 1A; D, ep) present in IX, in mid-ventral transverse furrow located just behind the line of spermathecal pores, up to $64 \mu \mathrm{m}$ tall, $38-54 \mu \mathrm{m}$ wide.

Somatic setae (Fig. 1B, C). Dorsal and ventral setal bundle consisting of 2 (or rarely 3) trifid setae in II-X, 74-174 $\mu \mathrm{m}$ long, 4-8 $\mu \mathrm{m}$ wide at node: upper tooth thinnest and shorter than middle; middle tooth longest; and lower tooth thickest and shortest with thin subdental ligament. Posterior to $\mathrm{X}$, somatic bundle consisting of only 1 seta, 67-128 $\mu \mathrm{m}$ long, 5-10 $\mu \mathrm{m}$ wide at node; setae bifid in segments immediately posterior to $\mathrm{X}$, but lower tooth gradually reduced in the more posterior segment and the setae become single-pointed at middle of the body. Thereafter lower tooth gradually emerging again, and setae become bifid again at the posterior end of the worm.

Genital setae. Ventral setae of XI modified into penial setae (Fig. 1D, ps), two per bundle; penial setae single-pointed, 176-214 $\mu \mathrm{m}$ long, 6.4-11.2 $\mu \mathrm{m}$ wide at middle part; ectal tips of penial setae directed towards ventro-posteriorly, protruding exterior from a single median cleft between male pores.

Internal somatic characters. Pharyngeal glands present in IV-V. Oesophagus not modified. Coelomocytes spherical, numerous in preclitellar segments; diameter $6-11 \mu \mathrm{m}$.

Male genitalia (Fig. 1D-F). All structures paired. Vas deferens long and irregularly coiled, 10-16 $\mu \mathrm{m}$ wide at both ends, 24-30 $\mu \mathrm{m}$ wide at middle part. Atrium tubular, M-shaped, $610-840 \mu \mathrm{m}$ long, $40-58 \mu \mathrm{m}$ wide, consisting of outer muscular lining $(5-11 \mu \mathrm{m}$ thick) and granulated and ciliated inner epithelium. Prostate glands broadly attached to the ventral surface of atrium, communicating with inner epithelium of atrium at many points. Ectal 1/4 of atrium without prostate gland, tapering ectally. Pseudopenis (Fig. 1D, pp; E) pear-shaped, 16-19 $\mu \mathrm{m}$ long, 14-19 $\mu \mathrm{m}$ wide.

Spermathecae (Fig. 1D). Paired, each consisting of two parts: (1) ectal duct with narrow lumen, 88-104 $\mu \mathrm{m}$ long, 32-43 $\mu \mathrm{m}$ wide at the ental end; and (2) large ampullae of varying shape, filling the most part of $\mathrm{IX}$ and $\mathrm{X}$ with wall containing large granules. Sperm in spermathecal ampulla as large masses.

Remarks

Heterodrilus mediopapillosus sp. $\mathrm{n}$. is distinguishable from all other congeners by having epidermal papilla between the spermathecal pores. Some species of Heterodrilus also have modified epidermis of this areas, which appears to function "as anchoring sites for tips of 

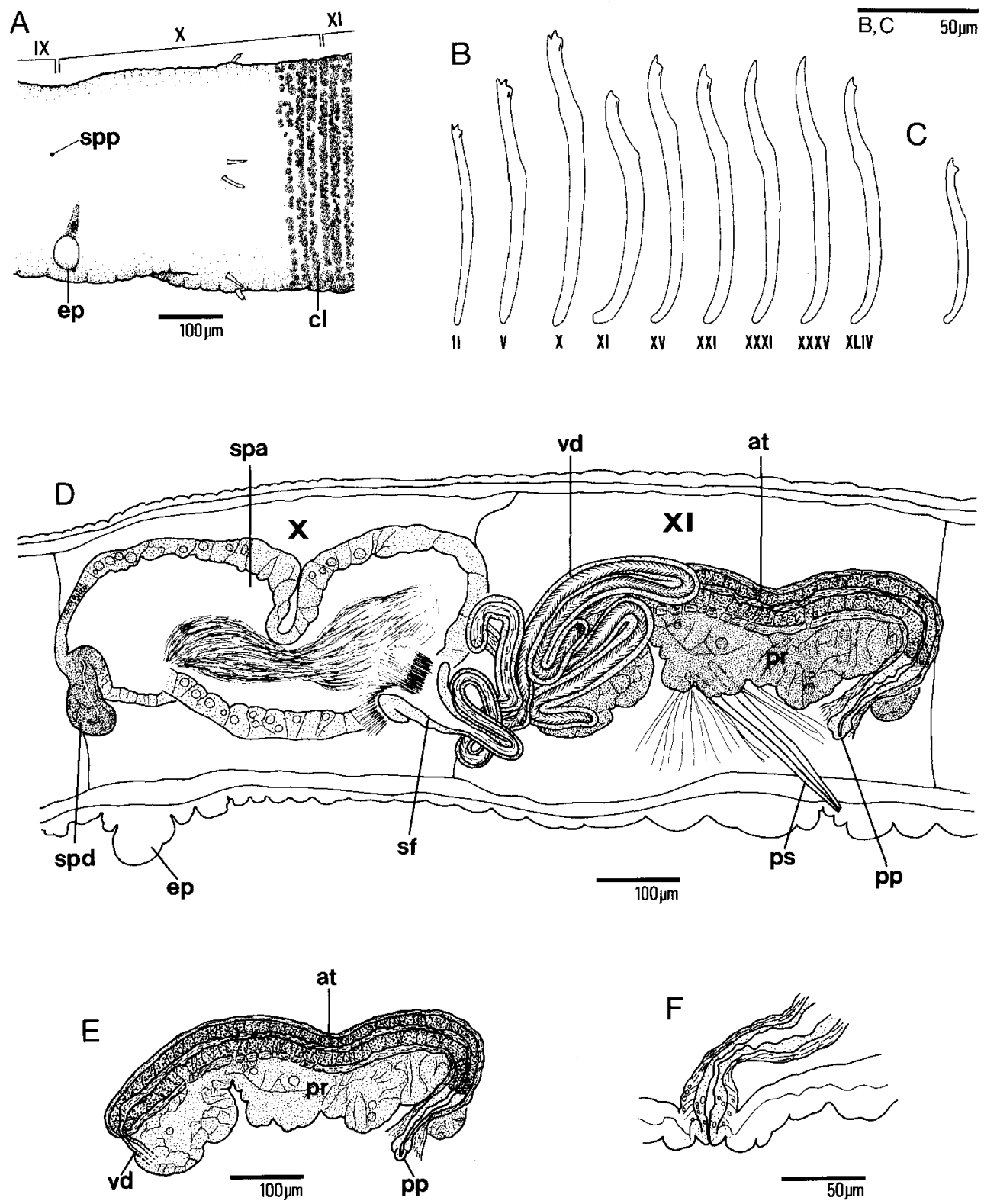

Fig. 1. Heterodrilus mediopapillosus sp. n. A: Ventro-lateral view of segment X (paratype, ZIHU 1048). B: Dorsal setae of various segments (holotype) C: Somatic seta of the posterior-most region of body (paratype, ZIHU 1044). D: Lateral view of spermatheca and male duct in segment IX-XI (holotype). E: whole-view of atrium and prostate gland (holotype). F: Lateral view of pseudopenis (paratype, ZIHU 1044).

penial setae" (in H. virilis in Erséus 1992: p. 161). Such structures were described variously in different species as "mid ventral slit on small epidermal pad" in $H$. claviatriatus and $H$. 
jamiesoni (Erséus, 1981: p. 118, 120), "a pair of epidermal crypts" in H. ersei (as Giereidrilus ersei, Erséus, 1981: p.127), "small epidermal papilla (in H. sp, Erséus, 1981: p. 124), which perhaps should be termed an epidermal pad" in $H$. pentcheff (Erséus, 1986: p. 290), and "unpaired transverse epidermal pad with two small pits" in $H$. virilis (Erséus, 1992: p. 161). The papilla of the present new species is much more protruded from the body surface than those so far reported which are only slightly thickened areas of epidermis with or without pits/slits.

Heterodrilus mediopapillosus sp. n. appears to be closely related to $H$. pentcheff Erséus, 1981 known from northwest Atlantic (United States, Bermuda, and Belize) and Galapagos Islands (Erséus, 1981, 1984, 1986, 1990a). The two species share setal arrangement and M-shaped atria. The present new species, however, differs from $H$. pentcheffi in having long penial setae and pear-shaped pseudopenes. In addition, the angle of the penial setae to the body axis is smaller, and the vasa deferentia are less regularly coiled in the present new species than in $H$. pentcheff; in the latter species the penial setae are almost perpendicular to body axis, and the vasa deferentia are spirally and tightly coiled. Heterodrilus mediopapillosus sp. n. also resembles $H$. virilis Erséus, 1992 from southern China. The two species share male terminalia of pear-shape, and straight penial setae that are much longer than those of the other congeners. The present new species, however, differs from $H$. virilis in having spermathecae (those organs lacking in the latter), M-shaped long atria and posterior somatic setae with reduced lower teeth.

Genus Aktedrilus Knöllner, 1935

Aktedrilus locyi Erséus, 1980

(Fig. 2, Tab. 1)

Aktedrilus locyi Erséus, 1980, p. 104, figs 2E, 8.

Aktedrilus locyi Erséus: Strehlow, 1982, p. 593, table 1; Erséus, 1984, p. 193; 1989, pp. 13-15, figs. 2a-f; 1992, p. 169-170, fig. 8.

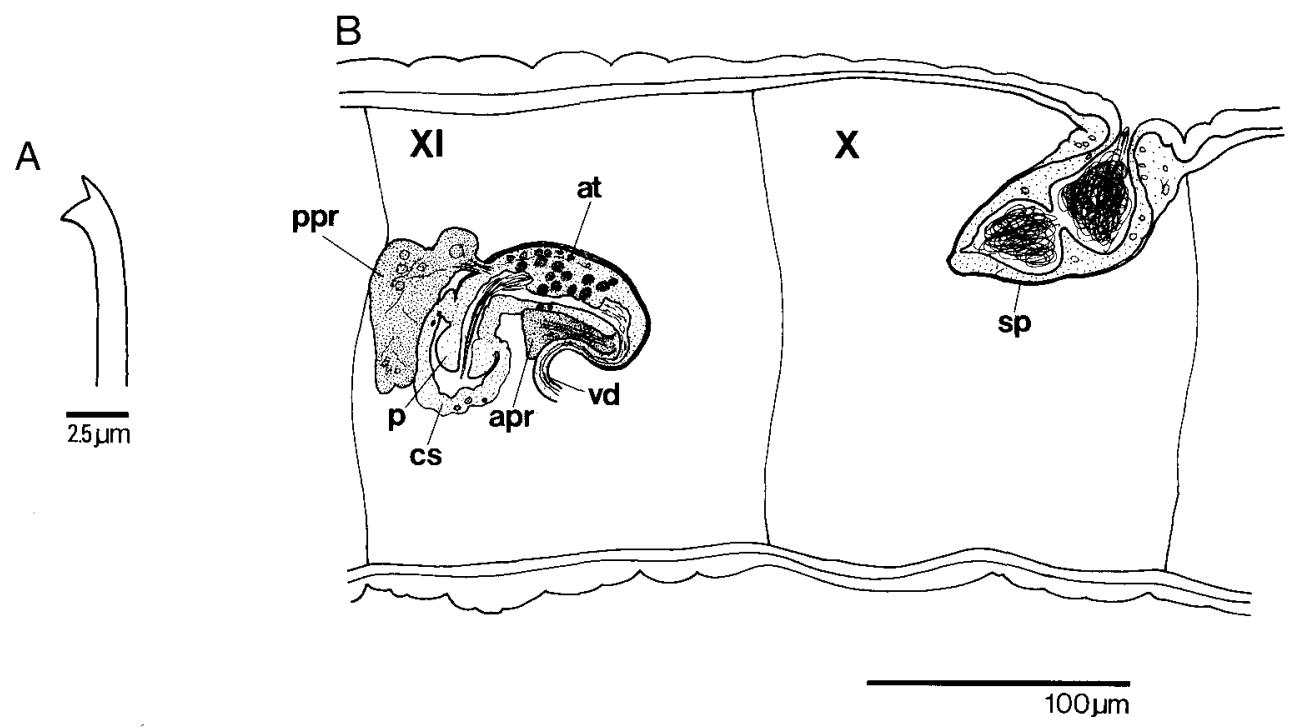

Fig. 2. Aktedrilus locyi (ZIHU 1050). A: Ectal tip of dorsal seta of VIII. B: Lateral view of spermatheca and male duct in segment IX-XI. 
Material examined

ZIHU 1049-1051, 3 whole-mounted specimens from Sakata-hana, Shirahama-cho, Wakayama Prefecture, Japan. Intertidal, gravel (3 December 1993).

Description of the present new material

External features. Length 3.3-4.8 $\mathrm{mm}$, number of segments 23-35 (shortest worm incomplete). Width $0.18-0.20 \mathrm{~mm}$ at XI. Prostomium blunt conical, slightly shorter than wide. Clitellum extending over $1 / 3$ X-XII. Male pores paired, in line with ventral setae, posteriorly in XI. Spermathecal pores mid-dorsal, in anterior-most part of X.

Setae. Dorsal and ventral setal bundle consisting of 3-5 bifid setae in preclitellar segments, but 3-4 bifids posteriorly; setae (Fig. 2A) with upper tooth as long as and thinner than lower, 22-30 $\mu \mathrm{m}$ long, $1.5 \mu \mathrm{m}$ wide at node. Ventral setae in XI absent.

Internal somatic characters. Pharyngeal glands present in IV-VI. Coelomocyte absent.

Male genitalia (Fig. 2B). All structures paired. Sperm funnel 26-32 $\mu \mathrm{m}$ wide, about as long as wide. Vas deferens $8-13 \mu \mathrm{m}$ wide, about as long as atrium, entering atrium apically. Atrium cylindrical, somewhat coiled, about 64-72 $\mu \mathrm{m}$ long, 18-27 $\mu \mathrm{m}$ wide, with distinct outer muscular layer (up to $1.5 \mu \mathrm{m}$ thick) and inner granulated and ciliated epithelium (2.5-6.4 $\mu \mathrm{m}$ thick). Atrium terminating into club-shaped penis, without cuticular sheath, 26-27 $\mu \mathrm{m}$ long, 22-26 $\mu \mathrm{m}$ wide at ectal tip. Penis enclosed into copulatory sac. Anterior prostate gland attached to ental-most part of atrium. Posterior prostate gland small, attached to ectal part of atrium, not communicated with copulatory sac.

Spermatheca (Fig. 2B). Unpaired in X. Length 72-93 $\mu \mathrm{m}$, width 32-42 $\mu \mathrm{m}$; ampulla oblong, thin walled, occupying ental half of spermatheca; duct thick walled with broad lumen. Sperm in a random mass in spermathecal ampulla or in both ampulla and duct.

Remarks

This series has been known from both western and eastern Pacific (Erséus, 1980, 1984, 1992; Strehlow, 1982) and Arabian Gulf (Erséus, 1989). This is the first record of Aktedrilus locyi from Japan, and the present material agree well with the previous descriptions. Aktedrilus locyi shows some variations between specimens from different localities (Table 1). The present material is similar to that from Hong Kong in the number of setae per bundle and the dimensions of male genitalia. Moreover, the specimens from the two localities share

Table 1. Comparison of Japanese specimens of Aktedrilus locyi with descriptions from different localities.

\begin{tabular}{lcccccc}
\hline & Erséus, 1980 & Strehlow, 1982 & Erséus, 1984 & Erséus, 1989 & Erséus, 1992 & Present study \\
\hline Location & California & Oregon & Galapagos & Saudi Arabia & Hong Kong & Japan \\
Length $(\mathrm{mm})$ & $1.5-1.8$ & $2.4-3.4$ & 1.4 & $1.4-1.8$ & - & $3.3-4.8$ \\
$\begin{array}{l}\text { Width }(\mathrm{mm}) \\
\text { No. of setae per }\end{array}$ & $0.09-0.11$ & - & - & $0.07-0.11$ & 0.23 & $0.18-0.20$ \\
anterior byndle & $2-4$ & $2-4$ & - & $2-4$ & $(3) 4-5(6)$ & $3-5$ \\
$\begin{array}{l}\text { Width of vasa } \\
\text { deferentia }(\mu \mathrm{m})\end{array}$ & $5-7$ & - & - & & & \\
Atria* & $65-85 \times 11-16$ & $75-105 \times 10-15$ & - & $40-60 \times 14-17$ & $60 \times 25$ & $64-72 \times 18-27$ \\
Penes* & $14-17 \times 12-18$ & $14-20 \times 7-20$ & - & $15-17 \times 12-15$ & $25 \times 23$ & $26-27 \times 22-26$ \\
Spermathecae* & $49-68 \times 22-33$ & - & - & $50-70 \times 20-28$ & $85 \times 32-40$ & $72-93 \times 32-42$ \\
\hline
\end{tabular}

* Length $\times$ greatest width $(\mu \mathrm{m})$ 
wider body and spermatheca than those of the materials from other localities.

Genus Limnodriloides Pierantoni, 1903

\section{Limnodriloides tenuiductus Erséus, 1982}

(Fig. 3)

Limnodriloides tenuiductus Erséus, 1982, pp. 247-248, fig. 26, table 3.

Limnodriloides tenuiductus Erséus: Erséus 1985, pp. 149-150,

fig. 14; 1990b, pp. 300-302, fig. 18.

Material examined

ZIHU 1052-1054, 3 whole-mounted specimens from Sakata-hana, Shirahama-cho, Wakayama

Prefecture, Japan. Intertidal, gravel (3 December 1993).

Description of the present new material

External features. Length $8.3-10.5 \mathrm{~mm}$; number of segments 35-46. Width $0.24-0.32$ $\mathrm{mm}$ at XI. Prostomium rounded, slightly longer than wide. Epidermal glands not observed. Clitellum extending over XI-XII. Male pores paired, in line with ventral setae, posteriorly in XI. Spermathecal pores paired, dorsal to lines of dorsal setae, middle of X.

Setae. Dorsal and ventral bundle consisting of 2 (rarely 1 or 3 ) bifid setae in II-VII
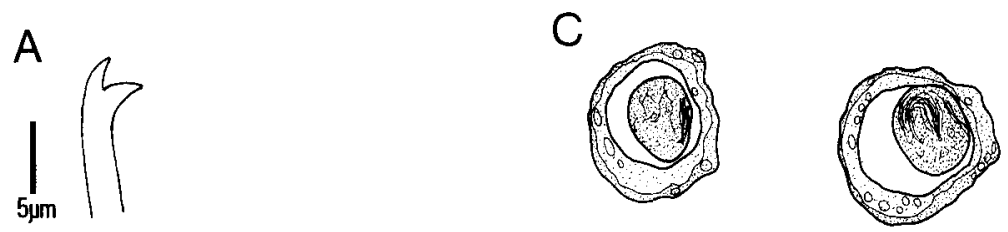

$50 \mu \mathrm{m}$

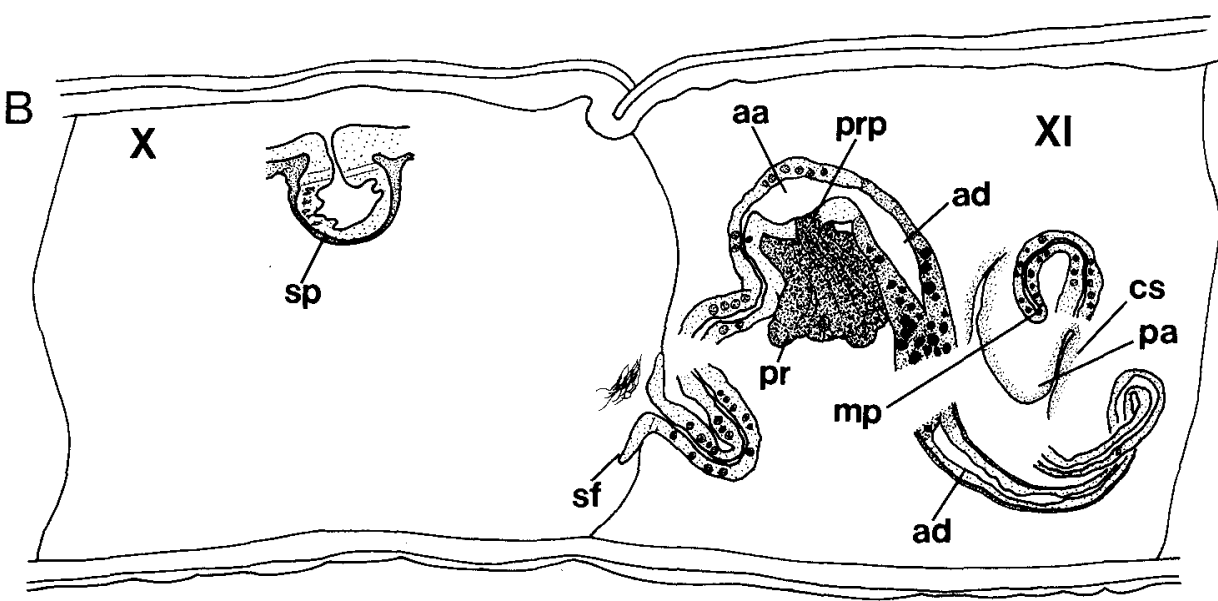

$100 \mu \mathrm{m}$

Fig. 3. Limnodriloides tenuiductus (ZIHU 1053). A: Ectal tip of dorsal seta of VIII. B: Lateral view of spermatheca and male duct in segment IX-XI. C: Spermatheca and sperm mass (ZIHU 1054). 
(or VIII), but 1 bifid thereafter; setae (Fig. 3A) with upper tooth shorter and thinner than lower, 35-67 $\mu \mathrm{m}$ long, 2-4 $\mu \mathrm{m}$ wide at node. Setae totally absent in X and XI. Internal somatic characters. Pharyngeal glands present in IV-V. Coelomocyte absent. A pair of oesophageal diverticula present in IX.

Male genitalia (Fig. 3B). All structures paired. Sperm funnel $56 \mu \mathrm{m}$ wide, about as long as wide. Vas deferens $210 \mu \mathrm{m}$ long, 12-19 $\mu \mathrm{m}$ wide, entering atrium apically. Atrial ampulla spherical, $56 \mu \mathrm{m}$ long, $40 \mu \mathrm{m}$ wide; prostatic pad situated on mid-ventral part of ampulla. Atrial duct bipartite: ental part $130 \mu \mathrm{m}$ long, $32 \mu \mathrm{m}$ wide, with granulated inner epithelium; ectal part about twice as long as ental granulated part, 16-21 $\mu \mathrm{m}$ wide, not granulated, somewhat coiled. Atrial duct terminating in pseudopenial papilla enclosed in copulatory sac.

Spermathecae (Fig. 3B). A pair in X. Each consisting of very short duct and thin walled spherical ampulla (about $50 \mu \mathrm{m}$ diameter). Only one postcopulatory specimen (ZIHU 1054) has globular sperm mass in spermathecal ampulla.

\section{Remarks}

This is the first report of Limnodriloides tenuiductus from Japan. This species was originally described from Great Barrier Reef, Eastern Australia by Erséus (1982), and subsequently reported from the Arabian Gulf Coast of Saudi Arabia (Erséus, 1985) and southern China (Erséus, 1990b). The present material, like the Arabian specimens, lacks epidermal glands. However, as Erséus (1990b) suggests, there is a possibility that such glands are only visible in material which was fixed in Bouin's fluid (the present specimens were fixed by ethanol). In other respects, the Japanese material conforms well with the previous descriptions, except for the following two points (corresponding condition in other materials in parentheses): (1) spermathecae spherical (oval to elongated); and (2) sperm in spermathecae forming a globular mass (slender spermatozeugmata). These inconformities are probably due to different degree of maturity, for none of the present specimens are fully mature: two specimens among the present three were precopulatory with male genitalia being still under development; the remaining one was postcopulatory with partly degenerated male genitalia. Globular masses of sperm observed in the latter specimen might be degenerating spermatozeugmata.

\section{Acknowledgements}

We are grateful to Dr M. J. Weedon (reserch fellow, Division of Biological Sciences, Graduate School of Science, Hokkaido University) for his critical reading of the manuscript and for improving the English text. Professor C. Erséus (Swedish Museum of Natural History) kindly provided some taxonomic advice. Cordial thanks are also due to $\mathrm{Dr} \mathrm{S}$. Kubota, $\mathrm{Mr}$ K. Okita and Mr Y. Yamamoto (Seto Marine Biological Station, Kyoto University) for their kind support in collecting specimens.

\section{References}

Baker, H. R. \& R. O. Brinkhurst. 1981. A revision of the genus Monopylephorus and redefinition of the subfamilies Rhyacodrilinae and Branchiurinae (Tubificidae: Oligochaeta). Can. J. Zool., 59: 939-965.

Brinkhurst, R. O. 1985. A further contribution to the taxonomy of the genus Tubificoides Lastockin (Oligochaeta: Tubificidae). Can. J. Zool., 63: 400-410.

Erséus, C. 1980. Taxonomic studies on the marine genera Aktedrilus Knöllner and Bacescuella Hrabě (Oligochaeta, Tubificidae), with descriptions of seven new species. Zool. Scr., 9: 97-111. 
Erséus, C. 1981. Taxonomic revision of the marine genus Heterodrilus Pierantoni (Oligochaeta, Tubificidae). Zool. Scr., 10 111-132.

Erséus, C. 1982. Taxonomic revision of the marine genus Limnodriloides (Oligochaeta: Tubificidae). Verh. naturwiss. Ver. Hamburg (NF), 25: 207-277.

Erséus, C. 1984. Interstitial fauna of Galapagos. XXXIII. Tubificidae (Annelida, Oligochaeta). Microfauna Marina, 1: 19l-198.

Erséus, C. 1985. Annelida of Saudi Arabia. Marine Tubificidae (Oligochaeta of the Arabian Gulf Coast of Saudi Arabia. Fauna of Saudi Arabia, 6: 130-154.

Ersćus, C. 1986. Marine Tubificidae (Oligochaeta) at Hutchinson Island, Florida. Proc. biol. soc. Wash., 99: 286-315.

Erséus, G. 1989. Marine Tubificidae (Oligochaeta) of the Arabian Gulf Coast of Saudi Arabia (Part 5). Fauna of Saudi Arabia, 10: 11-19.

Erséus, C. 1990a. The marine Tubificidae (Oligochaeta) of the barrier reef ecosystems at Carrie Bow Cay, Belize, and other parts of the Caribbean Sea, with descriptions of twenty-seven new species and revision of Heterodrilus, Thalassodrilides and Smithsonidrilus. Zool. Scr., 19: 243-303.

Erséus, C. 1990b. Marine Oligochaeta of Hong Kong. In: Proceedings of the Second International Marine Biological Workshop: The Marine Flora and Fauna of Hong Kong and Southern China, Hong Kong, 1986. (ed. B. Morton). Hong Kong University Press, Hong Kong, pp. 259-335.

Erséus, C. 1992. Hong Kong's marine Oligochaeta: a supplement. In: The marine flora and fauna of Hong Kong and southern China III. Proceedings of the Fourth International Marine Biological Workshop: The Marine Flora and Fauna of Hong Kong and Southern China, Hong Kong, 11-29 April 1989 (ed. B. Morton). Hong Kong University Press, Hong Kong, pp. 157-180.

Ohtaka, A. 1987. New record of Tubificoides brevicoleus Baker (Oligochaeta, Tubificidae) from the Pacific coasts of Hokkaido, Northern Japan. J. Fac. Sci. Hokkaido Univ. Ser. VI, Zool, 25(1): $1-8$.

Strehlow, D. R. 1982. Aktedrilus locyi Erséus, 1980 and Aktedrilus oregonensis n. sp. (Oligochaeta, Tubificidae) from Coos Bay, Oregon, with notes on distribution with tidal height and sediment type. Can. J. Zool., 60: 593-596.

Takashima, Y. \& Mawatari, S. F. 1996. Marine Tubificidae (Oligochaeta) from Hokkaido, northern Japan, with descriptions of two new species. Species Diversity, 1: 55-70. 